\title{
Juvenile Offenders: Characteristics and Reasons Why They Drop out of Regular Education, in Valparaiso Region
}

\author{
Patricia Muñoz-Salazar ${ }^{1, *}$, Violeta Acuña-Collado ${ }^{2}$ \\ ${ }^{1}$ Faculty of Sociology, University of Playa Ancha, Chile \\ ${ }^{2}$ Faculty of Adult Education, University of Playa Ancha, Chile
}

Copyright $(2016$ by authors, all rights reserved. Authors agree that this article remains permanently open access under the terms of the Creative Commons Attribution License 4.0 International License

\begin{abstract}
In Chile, adult education has drastically transformed in recent decades, both in the curriculum reform and in the age of their students. Today, users of this education are no longer working adults who need to complete their studies to work, but they are mostly young teenagers who dropped out of regular education. The problem is that because their age they should be in the regular education, but they opt for adult education with teachers that are not prepared to deal with juvenile problems. This situation is even more complicated because adult education must receive young offenders because the Juvenile Criminal Responsibility Law establishes that they have to come back to school, but regular education has difficulties to accept them. However, they do not choose to come back to school and they have no motivation. This article presents the results of two quantitative researches conducted in 2008-2009 and in 2010-2011. These researches used random samples and together cover all the establishments that provided adult education in the Valparaiso Region. In both studies, the purpose was to characterize adolescents between 14 and 17 years-old and examine the reasons why they drop out of regular educational system and why they chose to continue their studies in the adult educational system.
\end{abstract}

Keywords Adult Education, Young Offenders, Adolescence at Risk

\section{Introduction}

In Chile, adult education has transformed in recent decades, both in the curriculum reform and in the age composition of their students. Today, the users of this education are no longer working adults who seek to complete their studies, but are mostly young people who may be in regular education, but have dropped out for various reasons such as repeated school failure, failure to adapt to the disciplinary rules of the establishment, return to work, family problems or pregnancy. According to the Ministry of Education, since 2005, the regular education dropout rates reaches 7.3\% (79,000 children / and young) among the secondary education population (1). This type of education was designed for adults but currently -in addition to young people who drop out of regular education- has to accept young offenders that by judicial resolution can choose programs at liberty, according to the seriousness of the offense. All these programs have as initial condition that young offenders go back to school but regular educational institutions place obstacles to accept them, because they do not want their students coexist with people that having the same age is convicted for committing crimes. In this context, a real educational option is adult education. Nonetheless, this option is far from being an adequate solution. First of all, it was designed having in mind responsible and highly motivated adults who want to complete compulsory education; and secondly, teachers are not prepared to teach young people with serious behavioral, psychological and social problems. In Chile, no university trains teachers for adult education so their curriculum does not prepare them to comply with the particularities of young offenders.

According to the Juvenile Criminal Responsibility Law accessing and continuing in the educational system is highly important, because it considers that the process safeguards the rights of the young and the achievement of rehabilitation and social reintegration. Adult education is an option provided by the National Service for the Minor (SENAME) which includes adult education centers or programs in flexible modalities. The Law No. 20,084 establishes a legal framework especially for adolescents who commit offenses. This framework focuses on empowerment through social and educational activities aimed at rehabilitation and social reintegration. However, neither has studied motivation with which these young people face the educational process.

The situation of young offenders in Chile has not been studied much, and its educational trajectory is mostly 
unknown. In order to shed light on this issue, this article aims to characterize young offenders who attend adult education centers and examine the reasons why they leave regular educational system and they choose to continue their studies in the adult education. The data used is originated from two quantitative researches conducted in 2008-2009 and in 2010-2011. In both researches, one of the objectives was to characterize adolescents which were mandatorily sent back to school.

\section{Methodology}

As it was mentioned before, the results presented in this article are originated from two social surveys that used random samples by conglomerates constituted by the adult education centers of the Valparaiso Region. In the study conducted in 2008-2009 was selected randomly the $50 \%$ of the educational centers and the survey was applied to all students who attend school while this field research was conducted. In this case, the sample was formed by 233 cases, in which 57 were offenders. The research conducted in 2010-2011 covered educational centers that were not considered in the first research including 220 cases, in which 63 were offenders. Both researches covered the total of centers that provide adult education in the region and here are presented the results corresponding to these offenders. The data was collected through a survey filled out by students themselves and was applied in the classroom under the guidance of pollsters duly trained, in the presence and collaboration of the teacher. In each school, the survey had to be taken in different days due to the high rates of absence that characterize this education modality, especially on Mondays and Fridays. The survey contained characterization questions and a dichotomic scale of 73 items to detect the reasons of dropping out of regular education and the subsequent entrance to adult education.

\section{Adolescence: A Risk Stage}

Adolescence is a stage of an individual's life cycle in which a youngster undergoes drastic physical, psychological and social changes, through which biopsychosocial maturation into adulthood is achieved. These changes represent challenges to social organization, school, family and the individual's behavior as the adolescent will require a series of adaptive processes to progress through the levels involved. This stage is a critical period because they are developing the skills needed to face adult life (2).

In addition, adolescence occurs in a context of highly significant relationships. For the majority of people family gives a sense of belonging and a sense of identity, which is tested before the onset of pubertal changes of one or more children. In addition are the tensions that affect the mother parent / care takers (guardians) who are in different vital stages of development. During the time of parenting, they are reviewing their own accomplishments to date in several areas, resulting in an urgency to achieve unfulfilled goals or give up on others, and the permanent stress of maintaining a certain standard of living, plus the pressures being experienced by their partner. All this creates an environment of stressors that requires a reorganization of the relationships of family members (3).

In this period of the life cycle, the adolescent exhibits very different characteristics depending on the context in which it occurs. Thus there would be several effects on teens and youths. In this environment, there are sometimes inhibitors to development and potential environmental inequities in access to services and opportunities, quality education, health, culture or sports. On the other hand, there is an availability and access to firearms, alcohol and drugs, as they are living in poor communities with little cohesion and social isolation (4). The concept of vulnerability refers to environments that hinder adolescent development by the lack of opportunities for the development of individual and group potential and the scarcity of resources and services. These factors may influence the experience of teenagers making it difficult for them to access conditions that promote human development. Among those in poverty, we see a higher frequency of psychological and behavioral disorders, including those associated with substance abuse and violation of the law (4).

Changes in adolescence predispose young people to adopt risk behaviors and engage in transgressive activities of the law, among which are criminal activity and consumption of psychoactive substances. Among the risk behaviors is the need for reassurance, transgression, group acceptance, the feeling of invulnerability, the rejection of adult assistance and susceptibility to environmental pressures. This may be because at this stage of development, self-identity is largely built and adolescents need to feel part of something, feel they are equal to others, but also different from others, especially the adult world, as well as discover their limits and capabilities (5).

\section{Adolescent Criminal Background System in Chile}

In 1989 the International Convention on the Rights of the Child was approved on behalf of the General Assembly of the United Nations, which began a major shift in the consideration of children. The convention proposes a conception of human rights in which the child is considered subject to the inherent dignity of all people and with the possibility to demand their rights against the state, community and family, who are forced to guarantee them. This instrument devoted a minimum framework for the recognition of rights for children, which had to register the laws and practices of countries that have ratified it. In the case of Chile, the convention was ratified in 1990 (8).

On the basis provided by the International Convention on 
the Rights of the Child, Chile began to work on Law No. 20,084 of Adolescent Criminal Responsibility (LRPA), which seeks to ensure the child and adolescents' universal human rights (6). This law which took effect in 2007 establishes a specialized criminal justice system that treats children and adolescents from 14 to 17 years (and 11 months) as subjects of rights, fully responsible for their actions and considers their personal human development. This system avoids the confusion between abandonment and violation of criminal laws, creating separate skills, administrative and judicial, in each case (6). This law considers the particular condition of being a teenager so that its procedures and consequences are different from adults. The sanctions emphasize the responsibility and also include a socio-component in intervening in order to promote social reintegration (5). To fulfill its objective of social reintegration, the system attempts to maintain adolescents in their social network and family, for it sees that deprivation of freedom causes more problems than it intends to solve and may even lead to reoccurrence and thereby the development of criminal careers (7). Therefore, these adolescents should be in a free environment while being placed in a penitentiary is the exception (8). Moreover, the law establishes that the teen has minimal contact with the judicial system in order to prevent damage to their development (9).

In spite of the attempts to comply with the recommendations emanated from the Convention on the Rights of the Child, with a special law for adolescents, Chile cannot accomplish the expectations to provide education proper to the reality of young offenders. They come from families in socioeconomic vulnerability, with major deprivation and in many opportunities with serious psychological problems. Also, they come back to school based on a decision imposed by a judge and not because they want to. This situation makes the teacher must work with unmotivated young with problems that already have a dropout background, which theoretically should be retained. Nevertheless, as it was mentioned before, in Chile no university or institute trains teachers for adult education, but instead they have to be self-taught and learn in practice (10).

\section{Adult and Youth Education in Chile}

The System of Youth and Adult Education has been increasing dramatically in recent decades; so for example, in 1990 there were 72,000 students, which increased to 384,000 in 2004. This demand was largely received by the regular education system (195,000 enrollments), followed by flexible modality (135,000 registrations) and a much smaller number through the program 'Contigo Aprendo' $(15,000$ enrollments) (1). In 2006, people over the age of 15, with incomplete education, amounted to 5,442,460 of which $3.49 \%$ was registered in adult education, 139,897 in regular mode and 50,161 in the flexible form (1).

The reform of adult education has tried to accommodate the interests and needs of those who attend this type of education in order to become a means of social integration that effectively helps people to cope better with changes in field work and society. This reform aims to improve the quality of learning, increase coverage and reduce the high dropout rates. To achieve these goals we have implemented a new management model based on educational and administrative decentralization in education. This new model transfers a set of pedagogical and curricular decisions from central agencies to educational institutions and teachers (11).

Currently Adult Education in Chile is immersed in the Standardization Program of Studies, which also includes the processes of validation studies. In this new stage, it is necessary to mention the Decree 332 of September 2011 that regulates the ages of the students entering this modality, which aims to reduce the high number of adolescents that enter there. Reference is made to this change, because the large number of young people, who migrated to Adult Education, will be slowed to the implementation of the present decree, and that young people should be part of the educational rehabilitation programs of the Ministry of Education. We are facing a scenario that can only be evaluated in a few years (12).

In spite of the reforms that attempt to improve the economic management and regulate decrees that try to break the flow of adolescents, adult education still maintains standardized contents, didactics and evaluation typical of regular education, because teachers are trained for this educational modality. As long as Chile does not train teachers prepared to attend the specific reality of vulnerable young people, such as young offenders, the dropout rates will not diminish, with all that implies (10). Hence the importance of the results of this research because it will allow us to know a little bit more about them, why they drop out regular education and why instead of coming back, they choose adult education. These data constitute a necessary input to any transformation aimed for designing educational programs for vulnerable young people, whether is adult education or other.

\section{Characterization of Juvenile Offenders in the Adult Education System}

Young offenders who continue studies in adult education are mostly men, who conformed the $72 \%$ in $2008-2009$ and $64 \%$ in 2010-2011. Meanwhile women were $28 \%$ and $36 \%$, respectively, in both periods.

Table 1. Gender.

\begin{tabular}{|c|c|c|}
\hline Gender & $\mathbf{2 0 0 8 - 2 0 0 9}$ & $\mathbf{2 0 1 0 - 2 0 1 1}$ \\
\hline Woman & $28 \%(16)$ & $36 \%(22)$ \\
\hline Man & $72 \%(41)$ & $64 \%(41)$ \\
\hline
\end{tabular}

Regarding marital status, the vast majority of young people are single (a) $90 \%$ and $92 \%$ in each period, $3 \%$ live 
unchanged and 7\% and 5\% respectively has another civil status.

Table 2. Civil Status.

\begin{tabular}{|c|c|c|}
\hline Marital Status & $\mathbf{2 0 0 8 - 2 0 0 9}$ & $\mathbf{2 0 1 0 - 2 0 1 1}$ \\
\hline Single & $90 \%(51)$ & $92 \%(58)$ \\
\hline Cohabitating & $3 \%(2)$ & $3 \%(2)$ \\
\hline Other & $7 \%(4)$ & $5 \%(3)$ \\
\hline
\end{tabular}

A $9 \%$ have children in $2008-2009$, while $8 \%$ are parent in the period of 2010-2011.

Table 3. Paternity

\begin{tabular}{|c|c|c|}
\hline Are they a parent? & $\mathbf{2 0 0 8 - 2 0 0 9}$ & $\mathbf{2 0 1 0 - 2 0 1 1}$ \\
\hline Yes & $9 \%(5)$ & $8 \%(5)$ \\
\hline No & $91 \%(52)$ & $92 \%(58)$ \\
\hline
\end{tabular}

Most young people live with both parents: $60 \%$ in 2008-2009 up to $69 \%$ in 2010-2011; and about $21 \%$ lives with their father or mother in 2008-2009 and $23 \%$ in 2010-2011. Moreover, 9\% lives alone in 2008-2009 and only $3 \%$ in the second period.

Table 4. Who do the adolescents live with?

\begin{tabular}{|c|c|c|}
\hline Live with: & $\mathbf{2 0 0 8 - 2 0 0 9}$ & $\mathbf{2 0 1 0 - 2 0 1 1}$ \\
\hline both parents & $60 \%(34)$ & $69 \%(43)$ \\
\hline mother or father & $21 \%(12)$ & $23 \%(14)$ \\
\hline alone & $9 \%(5)$ & $3 \%(2)$ \\
\hline partner & $2 \%(1)$ & --- \\
\hline with partner in family house & $2 \%(1)$ & $3 \%(2)$ \\
\hline other & $7 \%(4)$ & $2 \%(1)$ \\
\hline
\end{tabular}

The $30 \%$ of young people that was working in 2008-2009, drop to $27 \%$ in the next period.

Table 5. Work

\begin{tabular}{|c|c|c|}
\hline & $\mathbf{2 0 0 8 - 2 0 0 9}$ & $\mathbf{2 0 1 0 - 2 0 1 1}$ \\
\hline Yes & $30 \%(17)$ & $27 \%(17)$ \\
\hline No & $70 \%(40)$ & $73 \%(46)$ \\
\hline
\end{tabular}

Continuing with the researches, most of the adolescents receive help from family and / or a partner, which is the situation of $88 \%$ in the first period and $90 \%$ in the second. A significant proportion of these young people said they receive support from an institution to continue their studies, $26 \%$ in 2008-2009 and 31\% in 2010-2011. Moreover, young people that work to meet their needs reach the $16 \%$ in the first period and, $14 \%$ in the second. There were several combine answers, which means, they receive support from their parents and also, they work.

Table 6. Support received to continue studies

\begin{tabular}{|c|c|c|}
\hline Type of support & $\mathbf{2 0 0 8 - 2 0 0 9}$ & $\mathbf{2 0 1 0 - 2 0 1 1}$ \\
\hline Family and/or partner & $88 \%(50)$ & $90 \%(57)$ \\
\hline Job & $16 \%(9)$ & $14 \%(9)$ \\
\hline Some type of institution & $26 \%(15)$ & $31 \%(19)$ \\
\hline
\end{tabular}

The second purpose of this article is to describe the reasons young offenders adduce for dropping out regular education. The reason most frequently mentioned is related to the lack of motivation as a personal factor in both periods ( $49 \%$ and 56\% respectively). Another group of reasons relates to the educational system, as mentioned with high frequency in both periods considering the problems with teachers $(44 \%$ and $29 \%)$, not understanding the material $(30 \%$ and $35 \%)$, and not understanding teachers $(26 \%$ and $33 \%$ ). In addition, the study mentions having left school to take responsibility to be parent $(11 \%$ and $8 \%$ ) or because the family left them out of school (11\% and 26\%).

Table 7. Reasons for dropping out of regular education

\begin{tabular}{|c|c|c|}
\hline Type of reason & $2008-2009$ & $2010-2011$ \\
\hline $\begin{array}{c}\text { To take over the responsibilities } \\
\text { of a parent }\end{array}$ & $11 \%(6)$ & $8 \%(5)$ \\
\hline Problems with teachers & $44 \%(25)$ & $29 \%(18)$ \\
\hline $\begin{array}{c}\text { Do not understand what the } \\
\text { teacher is explaining }\end{array}$ & $26 \%(15)$ & $33 \%(21)$ \\
\hline Do not understand the materials & $30 \%(17)$ & $35 \%(22)$ \\
\hline No time to study & $18 \%(10)$ & $29 \%(18)$ \\
\hline Lack of motivation & $49 \%(28)$ & $56 \%(36)$ \\
\hline Need to work & $16 \%(9)$ & $18 \%(11)$ \\
\hline $\begin{array}{c}\text { The family took them out of } \\
\text { school }\end{array}$ & $11 \%(6)$ & $26 \%(16)$ \\
\hline
\end{tabular}

Moreover, this article aims at revealing the reasons why young offenders choose the adult education. Young people say they have opted for the current adult education instead of continuing in regular education for recommendations from family or friends $(65 \%$ in each of the periods under consideration or recommendation of any institution, $26 \%$ and $10 \%$ respectively). Another category of arguments is related to the characteristics of distance education such as hours of operation (81 in 2008-2009\% and 66\% in $2010-2011)$, offered by the system $(60 \%$ and $52 \%)$ or by being close to home ( $35 \%$ and $40 \%)$. In some cases the young people claims more than one reason.

Table 8. Why these adolescents decided to study in the school they are currently enrolled in?

\begin{tabular}{|c|c|c|}
\hline Type of reason & $\mathbf{2 0 0 8 - 2 0 0 9}$ & $\mathbf{2 0 1 0 - 2 0 1 1}$ \\
\hline $\begin{array}{c}\text { Proximity to home } \\
\begin{array}{c}\text { Recommendation from family or } \\
\text { friends }\end{array}\end{array}$ & $35 \%(20)$ & $40 \%(25)$ \\
\hline Recommendation from an institution & $26 \%(15)$ & $65 \%(41)$ \\
\hline Because of the system it offers & $60 \%(34)$ & $10 \%(6)$ \\
\hline Because of the schedule & $81 \%(46)$ & $66 \%(33)$ \\
\hline
\end{tabular}

Among the reasons that young people claim to have resumed their studies, they indicate that something was missing in their lives by $81 \%$ in $2008-2009$ and $77 \%$ in $2010-2011$, followed by family demands $(75 \%$ and $68 \%$ in each period). The other reasons given are of the instrumental and high school completion ( $70 \%$ and $77 \%$ in each period), apply for a job (56\% and 37\% respectively), current job 
demands $(32 \%$ and $33 \%)$ or meet new people $(40 \%$ and $44 \%)$. In this case, they mention more than one reason.

Table 9. Why these adolescents resumed his studies?

\begin{tabular}{|c|c|c|}
\hline Type of reason & $\mathbf{2 0 0 8 - 2 0 0 9}$ & $\mathbf{2 0 1 0 - 2 0 1 1}$ \\
\hline For family demands & $75 \%(43)$ & $68 \%(43)$ \\
\hline For current job requirements & $32 \%(18)$ & $33 \%(21)$ \\
\hline To apply for a job & $56 \%(32)$ & $37 \%(23)$ \\
\hline $\begin{array}{c}\text { To feel that something was missing } \\
\text { in his life }\end{array}$ & $81 \%(46)$ & $77 \%(48)$ \\
\hline To finish high school & $70 \%(40)$ & $77 \%(48)$ \\
\hline To meet new people & $40 \%(23)$ & $44 \%(27)$ \\
\hline
\end{tabular}

Among the reasons why they decided to continue their studies in adult education are: teachers are nice $(86 \%$ in 2008-2009 and $83 \%$ in 2010-2011), they can dress as they wish ( $79 \%$ and $80 \%$ respectively), they can work and study at the same time ( $72 \%$ and $71 \%$ respectively), it is easier $(68 \%$ and $63 \%)$, it is funnier $(67 \%$ and $68 \%)$ and they prefer these partners (68\% and $66 \%)$. Among reasons are also more flexibility in attendance (39\% and 27 respectively), time of arrival ( $49 \%$ and $48 \%$ ) and less demanding (56\% and $44 \%$ ). Young people also mention more than one reason.

Table 10. Reasons why they decided to continue studying in adult education

\begin{tabular}{|c|c|c|}
\hline Type of reason & $\mathbf{2 0 0 8 - 2 0 0 9}$ & $\mathbf{2 0 1 0 - 2 0 1 1}$ \\
\hline It's easier & $68 \%(39)$ & $63 \%(40)$ \\
\hline They like to wear what they want & $79 \%(45)$ & $80 \%(50)$ \\
\hline Attendance is not obligatory & $39 \%(22)$ & $27 \%(17)$ \\
\hline The arrival time is flexible & $49 \%(28)$ & $48 \%(30)$ \\
\hline They can work and study at the same time & $72 \%(41)$ & $71 \%(44)$ \\
\hline It's entertaining & $67 \%(38)$ & $68 \%(42)$ \\
\hline It's the same as regular education & $39 \%(22)$ & $37 \%(23)$ \\
\hline It's better than their regular education & $65 \%(37)$ & $64 \%(41)$ \\
\hline Teachers treat them well & $86 \%(49)$ & $83 \%(52)$ \\
\hline They like their classmates & $68 \%(39)$ & $66 \%(42)$ \\
\hline It is less demanding & $56 \%(32)$ & $44 \%(27)$ \\
\hline
\end{tabular}

\section{Conclusions}

One of the purposes of this article was to characterize the young offenders that currently are enrolled in adult education. Generally, it is possible to appreciate that the young offenders that continue their studies in adult education are mostly men, in both periods. Only in the second research, the number of women increased. Also, most of these young people are single and live with their parents; an average of $9 \%$ has children and an average of $28 \%$ in both studies, work.

In agreement with Luengo (2), adolescence is a stage of life, in which a youngster pass through drastic physical, psychological and social changes, through which bio-psychosocial maturation in adult life is achieved. It is important to learn to pay more attention to this stage due to the different contexts these adolescents live in, which at times lead them to assume adult behaviors. This is due largely to the fact that they have no support that enables them to move throughout life avoiding criminal behaviors if they do not have a proper psychological and social support system (13).

Among the reasons for dropping out of regular education, the answer more mentioned by students in both groups was the lack of motivation. Other reasons were related to the educational system. Youth from both groups mentioned frequently that they have problems with teachers and they do not understand the material. Therefore, this is a variable that needs to be studied by those working in regular education because it is necessary to search for the causes of dropout in the performance of teachers. Presently, these teachers are not considering the diversity of their students.

Considering the low age of the participants in adult education, it is interesting to note that over $8 \%$ in both groups mentioned that they have dropped out school to assume parenting responsibilities. In this situation, we must think what is happening to their families and with them. Besides looking for alternative jobs to take care of their children, they have to study because the justice system demands it. In this context, the study and analysis of adult education becomes relevant.

Regarding the selection of studying in adult education, adolescents reported they based their decision on the recommendation of others: family, friends or any institution they are linked. This shows the weight that primary relationships, family and friends have in their development and choices they make in their life.

Although young people that come to school have had troubles with the law, most of them study for personal fulfillment and declare that it was something that was missing in their lives. In a lesser degree they mentioned family demands. The other reasons given have an instrumental nature, e.g. to graduate from high school, apply for a job or to meet current job requirements. These reasons again emphasize the influence of family and social pressures on the opportunities and decisions of these young people.

Note that another interesting reason why adolescents decided to continue their studies in the adult educational system is that teachers treat them well, they can dress as they like, and their schedules allow them to work and study at the same time. As we see, all the reasons are related to the convenience of studying, relationships and ultimately to feel good. This establishes that if a young person feels comfortable and loved, they will have more probabilities to finish their education and will project better opportunities for themselves.

We can therefore conclude that it is necessary to have clear policies for these young people in order to reintegrate them socially and educationally. Their opinions show why at some point they do not follow the societal norm of 12 years 
to meet regular education as it is required by law, veering off course for social and educational reasons. This indicates clearly that public policy in education should be more efficient in order to reduce high dropout rates and prevent also a second dropout, and most importantly for these adolescents, to achieve the expected social reinsertion without returning to a criminal behavior.

\section{REFERENCES}

[1] MINEDUC (2008). El desarrollo y el estado de la cuestión sobre el aprendizaje y la educación de adultos (AEA). Informe Nacional de Chile, Ministerio de Educación. Coordinación Nacional de Educación de Adultos, Santiago, Chile.

[2] Luengo, X. (2003): Características de la adolescencia normal. En: Salud Sexual y Reproductiva en la Adolescencia. Molina, R.; Sandoval, J. y González, E. Capítulo 2, pp.16-23. Editorial Mediterráneo, Santiago de Chile.

[3] Minuchin, S. y Fishman, H. (2004). Técnicas de terapia familiar, Editorial Paidós, Buenos Aires, Argentina.

[4] Balardini (2000): La participación social y política de los jóvenes en el horizonte del nuevo siglo. CLACSO, Buenos Aires, diciembre de 2000.

[5] Lobato M. (2008): Equipos de tratamiento del consumo problemático de drogas de la red de salud: Percepciones, dificultades y desafíos ante la Ley 20.084 sobre Responsabilidad Penal Adolescente. Tesis para optar al grado de Magister, Universidad de Chile, Departamento de psicología, Santiago, Chile.

[6] De Ferrari, I. (2006). Notas sobre la génesis y desarrollo de la Ley de Responsabilidad Penal Adolescente de Chile. En UNICEF, Justicia y Derechos del niño. Artículos para el Debate. Santiago, Chile.

[7] Viano, C. y Soto, P. (2007) Debates Penitenciarios Nº4. Centro de Estudios en Seguridad Ciudadana, Instituto de Asuntos Públicos, Universidad de Chile. Santiago, Chile.

[8] Duce, M. (2008). La Reforma procesal Penal en Chile: Logros y desafíos, periodo 2000-2007. Revista Latinoamericana de Seguridad Ciudadana, №3, pp.67-84.

[9] Ministerio de Justicia (2005). Historia de la Ley 20.084. El sistema de responsabilidad de los adolescentes por infracción a la ley penal. 7 de diciembre 2005. Disponible en el sitio www.ben.cl. (Biblioteca del Congreso Nacional).

[10] Muñoz-Salazar, P. (2015). Un acercamiento a la desconocida realidad de los jóvenes infractores de ley en la educación de adultos en Valparaíso. Valparaíso, Chile: Universidad de Playa Ancha.

[11] Ministerio De Educación (MINEDUC) (2004).Políticas de Educación de Adultos, Coordinación Nacional, Documento de Trabajo, Chile.

[12] Ministerio De EducacióN (MINEDUC) (2009). Ley Orgánica Constitucional de Enseñanza, Chile.

[13] Ministerio De Educación (MINEDUC) (2001). Diagnóstico de Educación de Adultos, Coordinación Nacional, Documento de Trabajo, Chile.

[14] Cillero, M. (2006). Comentario de la Ley de Responsabilidad Penal de Adolescentes de Chile. En UNICEF Justicia y Derechos del niño. Artículos para el Debate. Santiago, Chile 